\title{
Morpho-physiological characteristics of corn (Zea mays L.) affected by drought during its vegetative stage
}

\author{
Castro-Acosta, María de la Luz ${ }^{1}$; Sánchez-Soto, Bardo H. ${ }^{2}$; Ruelas-Islas, Jesús R. ${ }^{1}$; \\ Romero-Félix, Gelia S. ${ }^{{ }^{*}}$; Buelna-Tarín, Salomon ${ }^{1}$; Almada-Ruíz, Víctor G. ${ }^{1}$ \\ ${ }^{1}$ Universidad Autónoma de Sinaloa, Calle 16 y Avenida Japaraqui, Juan José Ríos, Ahome, Sinaloa, México. \\ C.P 81110 \\ 2 Universidad Autónoma de Occidente. Blvd. Macario Gaxiola y Carretera Internacional, Los Mochis, Sin, \\ México. CP. 81228. \\ * Autor para correspondencia: celiaromero82@hotmail.com
}

Gitation: Castro-Acosta, María de la Luz, Sánchez-Soto, Bardo H., RuelasIslas, Jesús R., Romero-Félix, Celia S. Buelna-Tarín, Salomon, Almada-Ruíz, Victor G. (2021). Morpho-physiological characteristics of corn (Zea mays $\mathrm{L}$.) affected by drought during its vegetative stage. Agro Productividad. https://doi. org/10.32854/agrop.v14io.1960

Editor in Chief: Dr. Jorge Cadena Iñiguez

Received: February, 2021.

Accepted: August, 2021

Agro Productividad, 14(8). August. 2021 pp: 71-77.

This work is licensed under a Creative Commons Attribution-NonCommercial 4.0 International license.

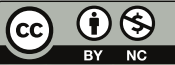

\section{ABSTRACT}

Objective: To evaluate the response corn hybrids have on their growth of aerial and root parts, transpiration, and water use efficiency during their early vegetative stage in irrigation and drought conditions.

Design/methodology/approach: A randomized complete block design with a factorial arrangement, three repetitions, three corn hybrids and two humidity levels were used. The evaluated variables were: plant height, leaf area, root length, dry weight of the aerial and root part of the plants, efficiency in the water use and total plant transpiration.

Results: The leaf area and dry weight data of the aerial parts of the assessed plants were greater in irrigation than in drought; in contrast, root length, dry root weight and water use efficiency were higher in drought. SV 3245 registered a higher total transpiration per plant; SV 3243 and ASGROW 7543 showed higher dry weight in their aerial parts; ASGROW 7543 accumulated a greater dry weight at their roots and was more water usage efficient. The experiments indicated interaction for root length, dry root weight and efficiency in water use. Limitations on study/implications: The drought caused seedlings' death at 28 days after sowing (dds), therefore, it was not possible to continue the evaluations from then on.

Findings/conclusions: The drought decreased the growth of the aerial parts of the plants and increased the root system and water use efficiency.

Keywords: water use efficiency, transpiration, dry weight, drought.

\section{INTRODUCTION}

Corn (Zea mays L.) is one of the most important crops. It has several uses, such as fodder, human consumption, fuel, among others. However, it is affected by drought, which modifies some of its morphological, physiological, biochemical, and molecular characters 
to cope with water stress (Nezhadahmadi et al., 2013; Polania et al., 2017). Drought affects corn yield and development depending on the severity and the developmental stage in which the plants are exposed to stress (Ge et al., 2012), the vegetative stage is the one with the higher water demand $(40.3 \mathrm{~cm}$ of lamina) than the reproductive stage $(23.2 \mathrm{~cm}$ of lamina) (Inzunza-Ibarra et al., 2018). When drought coincides with the vegetative period, leaf area development (17.1\%) (Villalobos-González et al., 2016) and photosynthetic rate decreases, these reductions in photosynthetic area and photosynthetic activity of the plants reflects in decreased cob and grain production during the two flowering weeks (Bänziger et al., 2012). Therefore, it is important to assess the morphological and physiological characters of plants during their early vegetative stages, if maximizing their water usage of and nutrients and increasing yield is intended, especially in environments where water scarcity prevails; this may be achieved by obtaining high dry matter production in the leaves and increasing carbon accumulation (Geiger et al., 1989), increasing light capture and efficient usage, biochemical modification of the photosystems and improved allocation of assimilates to the economic part of the plant (Blum, 2013), increased water use efficiency by improving carbon gain by increasing photosynthetic biochemistry and plant response or through increased mesophyll conductance (Condon, 2020), increased biomass productivity per water unit use and conversion of vegetative biomass to economic yield are the main objectives of drought research (Krishnamurthy et al., 2007). Coupled with this, it is also important to consider some root traits, such as soil moisture capture for transpiration, root architecture, and with this contribute to the improvement of water use efficiency, these root traits are determinants for improving C4 plants yield under drought stress (Ali et al., 2017). Root systems are complex, during the last decade, traits that contribute to adaptation to various types of stresses have been identified (Chen et al., 2019). A well-developed root system with sufficient elongation is important to improve plant growth, especially in water- and nutrient-deficient environments (Khan et al., 2012). Therefore, understanding root physiology in drought could influence crop productivity under stress conditions and contribute to the selection and development of resistant varieties, to maintain yield and ensure food security (Pandey and Shukla, 2015).

Research on the effect of drought on the growth and development of plants during the vegetative stage is scarce, it is, therefore, important to evaluate the behavior of plants under limited soil moisture conditions during their vegetative period. The objective of this work was to evaluate the response of three corn hybrids in the growth of aerial and root structures of the plant, transpiration, and water usage efficiency during the early vegetative stage under controlled irrigation and drought conditions.

\section{MATERIALS AND METHODS}

This study took place at the Carlos Darwin Herbarium of the Faculty of Agriculture of Valle del Fuerte, Juan José Ríos, Ahome, Sinaloa, Mexico (25 $44^{\prime}$ north latitude and $108^{\circ} 48^{\prime}$ west longitude, at $14 \mathrm{~m}$ ), during summer 2018, in irrigated and drought conditions in polyurethane containers. A clay-loam soil was used (35\% sand, 30\% silt and 10\% clay). Three commercial corn hybrids were evaluated: SV 3243, ASGROW 7573 and SV 3243. 


\section{Experimental design and treatments}

The sowing occurred on June 19, 2018. The experiment had two soil moisture treatments: irrigation (I) with water applied from sowing to 28 days after sowing (dds) and drought (D), where water was suspended from 19 dds on (when the plants had four leaves). The genotypes were assigned to a randomized complete block design with three repetitions in I and three in D treatments; The experimental unit consisted of an individual plant, grown in a three $\mathrm{kg}$ soil container. Each of the containers was filled with a soil $(60 \%)$ and sand $(40 \%)$ mixture. The soil was watered and once the water stopped draining, its weight was recorded and set as the initial weight at field capacity (IWFG) in each experimental unit.

In the drought treatments, the containers were weighed every third day, to calculate the lost amount of water from direct evaporation in the soil and add the required water to maintain each container's soil moisture level close to the IWFG from planting to 28 das. The procedure in the $\mathrm{D}$ treatments was the same as in I; however, 19 days after the beginning of the irrigation it was suspended, and the container's weight was recorded 28 days after the end of the experiment.

\section{Evaluated Variables}

Plant height $(\mathrm{PH}, \mathrm{cm})$ : measured from the base of the plant to the apex of the longest leaf.

Leaf area per plant $\left(\mathrm{FA}, \mathrm{cm}^{2}\right)$ : the area $\left(\mathrm{cm}^{2}\right)$ of the leaves was measured by multiplying the length $(\mathrm{cm}) \times$ width $(\mathrm{cm}) \times 0.75$ (Villalobos-González et al., 2019) at 28 das.

Root length $(\mathrm{LR}, \mathrm{cm})$ : determined by measuring the total length from the nodal region to the apex of the longest root.

Shoot dry weight (SDW, g): assessed by adding the accumulated dry matter in the vegetative aerial organs (stem and leaves) after samples were dried in an oven (Riossa ${ }^{\circledR}$ ).

Root dry weight (RDW, g): determined by obtaining the dry weight in an oven (Riossa ${ }^{\circledR}$ ) at $70^{\circ} \mathrm{C}$ for 48 hours.

Total transpiration per plant $\left(\mathrm{T}_{\mathrm{T}}, \mathrm{kg}\right)$ : calculated as the difference between the IWFC and the weight of the container assessed every third day and subsequently adding each obtained value.

Water use efficiency for total plant biomass production WUE $_{\mathrm{TBP}}, \mathrm{g}$ of $\mathrm{TBP} / \mathrm{kg}$ of evapotranspired $\left.\mathrm{H}_{2} \mathrm{O}\right)$ : calculated by dividing the total plant biomass $(\mathrm{SDW}+\mathrm{RDW}) / \mathrm{T}_{\mathrm{T}}$.

\section{Statistical analysis}

An analysis of variance (ANOVA) was performed in the SAS statistical program in combined $\mathrm{R}$ and $\mathrm{S}$ form, as a series of experiments $\left(Y_{i j k}=\mu+H_{i}+G_{j}+H G_{i j}+B_{(i) j}+E_{i j k}\right)$, to determine the differences between the soil moisture treatments $(\mathrm{H})$, genotypes $(\mathrm{G})$ and the $\mathrm{G} \times \mathrm{H}$ interaction, and an individual $\operatorname{ANOVA}\left(Y_{i j}=\mu+G_{i}+B_{j}+E_{i j}\right)$ for irrigation and continued in those response variables in which there was a significant effect of the $\mathrm{G} \times \mathrm{H}$ interaction. The comparison of means was carried out with the Tukey test $(\mathrm{P} \leq 0.05)$. 


\section{RESULTS AND DISCUSSION}

The adequate edaphic humidity conditions during the crop's vegetative stage favor the expansion of the foliar area and accumulate dry weight in the aerial parts of plants, contrary to this, under water deficit, even for short periods, drought affects these characters of plants. In drought conditions, the foliar area and dry weight of the aerial parts of plants decreased 52 and $69 \%$ in relation to the irrigation treatments, while the root length, the dry weight of the root and the efficiency in the use of water were $14 \mathrm{~cm}, 46 \%$ and $23 \%$ higher in drought than in irrigation (Table 1), respectively. Plant height and total transpiration per plant were not statistically different $(\mathrm{P}>0.05)$.

The dry weight decrease in the aerial parts of the plants or biomass was greater $(69 \%)$ than the reduction in biomass (13-34\%) reported by Mi et al. (2018) in corn plants under drought conditions during their vegetative stage at the field conditions, in China. In other research of drought conditions, greater root length has also been reported in corn (Zhu et al., 2010), increased dry weight of the roots (Chen et al., 2019) and high water use efficiency (Polania et al., 2017) compared with irrigation conditions. Plants respond to environmental stimuli to protect themselves; Lamers et al. (2020) indicate that plants have developed sophisticated adaptation mechanisms to resist the different abiotic stressors to which they are exposed.

The foliar area significantly decreased due to the drought effect. Villalobos-González $e t$ al. (2016) consider that drought during the vegetative stage of the corn crops has a greater effect on the expansion of their foliar area since it is the moment in which their leaves are in full expansion and their water deficiency reduces their elongation speed, this respect to the reproductive stage in which the leaves have fully extended the leaf area.

The means comparison between genotypes in average irrigation and drought showed that the SV 3245 hybrid had a higher total transpiration per plant; SV 3243 and ASGROW 7543 showed superior accumulation of dry weight in the aerial part of the plant; and ASGROW 7543 stood out for obtaining the highest accumulation of dry weight in the root and efficiency in the use of water than the other genotypes (Table 2). Plant height, leaf area and root length were statistically equal $(\mathrm{P}>0.05)$ (Table 2).

Corn is susceptible to drought, a solution strategy is to generate tolerant lineages from a segregating population to obtain hybrids or synthetic varieties (Rebolloza-Hernandez et al., 2020), based on contrasting humidity environments (Kebede et al., 2013), and in different phenological stages of the crop, especially during their vegetative stage, since it is in this period that drought reduces the establishment of the seedling (Bänziger et al., 2012).

Table 1. Comparison of means for morphological and physiological characteristics of corn hybrids under irrigation and drought conditions.

\begin{tabular}{l|c|c|c|c|c|c|c}
\hline Soil moisture & $\mathbf{P H}(\mathbf{c m})$ & $\mathbf{L A}\left(\mathbf{c m}^{2}\right)$ & $\mathbf{R L}(\mathbf{c m})$ & $\mathbf{S D W}(\mathbf{g})$ & $\mathbf{R D W}(\mathbf{g})$ & $\mathbf{T}_{\mathbf{T}}(\mathbf{k g})$ & $\mathbf{W U E}\left(\mathbf{g ~ k g}^{-\mathbf{1}}\right)$ \\
\hline Irrigation & $10.43 \mathrm{a}$ & $55.96 \mathrm{a}$ & $10.38 \mathrm{~b}$ & $0.13 \mathrm{a}$ & $0.07 \mathrm{~b}$ & $0.87 \mathrm{a}$ & $0.24 \mathrm{~b}$ \\
\hline Drought & $10.33 \mathrm{a}$ & $28.80 \mathrm{~b}$ & $23.95 \mathrm{a}$ & $0.09 \mathrm{~b}$ & $0.13 \mathrm{a}$ & $0.83 \mathrm{a}$ & $0.31 \mathrm{a}$ \\
\hline Tukey $(\mathrm{P} \leq 0.05)$ & 1.27 & 22.55 & 3.34 & 0.01 & 0.01 & 0.08 & 0.05 \\
\hline
\end{tabular}

PH=Plant height; LA=Leaf area; RL=Root length; SDW=shoot dry weight; RDW=Root dry weight; TT $=$ Total transpiration per plant; WUE $=$ Water use efficiency for produce total plant biomass. Means with the same letter in each column are statistically equal (Tukey, $\mathrm{P} \leq 0.05)$. 
Table 2. Comparison of means for morphological and physiological characteristics of corn hybrids in average irrigation and drought.

\begin{tabular}{|c|c|c|c|c|c|c|c|}
\hline Genotype & PH (cm) & $\mathrm{LF}\left(\mathrm{cm}^{2}\right)$ & $\mathbf{R L}(\mathbf{c m})$ & SDW (g) & RDW (g) & $\mathbf{T}_{\mathbf{T}}(\mathbf{k g})$ & WUE $\left(\mathrm{g} \mathrm{kg}^{-1}\right)$ \\
\hline SV 3245 & $9.80 \mathrm{a}$ & $34.46 \mathrm{a}$ & $17.22 \mathrm{a}$ & $0.08 \mathrm{~b}$ & $0.08 \mathrm{~b}$ & $0.96 \mathrm{a}$ & $0.19 \mathrm{~b}$ \\
\hline SV 3243 & $10.62 \mathrm{a}$ & $55.34 \mathrm{a}$ & $17.33 \mathrm{a}$ & $0.12 \mathrm{a}$ & $0.04 \mathrm{c}$ & $0.82 \mathrm{~b}$ & $0.26 \mathrm{~b}$ \\
\hline ASGROW 7543 & $10.80 \mathrm{a}$ & $37.34 \mathrm{a}$ & $14.28 \mathrm{a}$ & $0.14 \mathrm{a}$ & $0.18 \mathrm{a}$ & $0.80 \mathrm{~b}$ & $0.39 \mathrm{a}$ \\
\hline Tukey $(\mathrm{P} \leq 0.05)$ & 1.95 & 35.45 & 5.11 & 0.02 & 0.02 & 0.13 & 0.09 \\
\hline
\end{tabular}

$\mathrm{PH}=$ Plant height; LA=Leaf area; RL=Root length; SDW=shoot dry weight; RDW=Root dry weight; TT=Total transpiration per plant; WUE $=$ Water use efficiency for produce total plant biomass. Means with the same letter in each column are statistically equal (Tukey, $\mathrm{P} \leq 0.05)$.

The combined analysis of variance (ANOVA) detected significant effects $(\mathrm{P} \leq 0.05)$ in the interaction between genotypes $\times$ moisture levels for root length, root dry weight and water use efficiency (Figure 1); the three hybrids showed high values in root length (Figure 1a), root dry weight (Figure 1b) and water use efficiency (Figure 1c) in drought conditions with respect to the irrigation, except for the SV 3243 genotype which its efficiency in water usage in drought decreased conditions (Figure 1c).


Figure 1. Root length (a), root dry weight (b) and water use efficiency for total plant biomass production (c) of three corn hybrids. Juan José Ríos, Ahome, Sinaloa, Mexico. Bars indicate the standard deviation. Equal letters for each genotype at each moisture level are not statistically different (Tukey, $\mathrm{P} \leq 0.05$ ). 
The individual ANOVA for the irrigation conditions showed that the SV 3245 genotype had greater root length (Figure 1a); and ASGROW 7543 and SV 3243 had higher water use efficiency (Figure 1c). There were no statistically significant differences for root dry weight (Figure 1b); in drought, ASGROW 7543 exhibited high values of root dry weight (Figure 1b) and water use efficiency (Figure 1c) compared to the other genotypes. The root length was not different between genotypes $(\mathrm{P}>0.05)$ (Figure 1a).

Although this research was taking place during the seedling period, other researchers have reported similar results in the dry matter accumulation in the roots during the reproductive stage; Villalobos-González et al. (2018) when evaluating hybrid and creole corn varieties in contrasting humidity environments, found that the accumulation of dry matter in the roots was greater in drought than in irrigation conditions. For their part, Tracy et al. (2020) mention that the root system determines water and nutrients for photosynthesis and harvested products, which sustains agricultural productivity.

\section{CONGLUSIONS}

The morpho-physiological characteristics of the three hybrids were affected by soil water deficit; the dry weight of the aerial structures of the plants and their foliar area decreased in drought conditions compared to irrigation. In contrast, root length, root dry weight, and water use efficiency were higher in drought than in irrigation.

The hybrid ASGROW 7543, in average irrigation and drought, was outstanding for exhibiting better behavior in accumulation of the dry weight of the aerial and root part of the plant, greater efficiency in the use of water and low total transpiration per plant. In addition, drought showed high efficiency in the use of water and root dry weight.

\section{REFERENGES}

Ali, F., Ahsan, M., Ali, Q., and Kanwal, N. (2014). Phenotypic stability of Zea mays grain yield and its attributing traits under drought stress. Frontiers Plant Science 8(1397): 189-197. https://doi.org/10.3389/ fpls.2017.01397

Bänziger, M., Edmeades, G.O., Beck, D., y Bellon, M. (2012). Mejoramiento para aumentar la tolerancia a sequía y a deficiencia de nitrógeno en el maíz: In: CIMMYT. (Ed.). De la teoría a la práctica. México, D. F., GIMMYT. 61 p.

Blum, A. (2013). Heterosis, stress, and the environment: a possible road map towards the general improvement of crop yield. Journal of Experimental Botany 64(16): 4829-4837. https://doi.org/10.1093/jxb/ert289

Condon, A.G. (2020). Drying times: plant traits to improve crop water use efficiency and yield. Journal Experimental Botany 71: 2239-2252. doi.org/10.1093/jxb/eraa002

Chen, X., Mo, X., Hu, S., and Liu, S. (2019). Relationship between fluorescence yield and photochemical yield under water stress and intermediate light conditions. Journal of Experimental Botany 70(1): 301-313. doi:10.1093/jxb/ery341

Chen, Y., Palta, J.A., Wu, P., and Siddique, K.H.M. (2019). Crop root systems and rhizosphere interactions. Plant Soil 439: 1-5. https://doi.org/10.1007/s11104-019-04154-2

Ge, T.D., Sui, F.., Bai, L.P., Tong, C.L., Sun, N.B. (2012). Effects of water stress on growth, biomass partitioning, and water-use efficiency in summer maize (Zea mays L.) throughout the growth cycle. Acta Physiologiae Plantarum 34: 1043-1053. https://doi.org/10.1007/s11738-011-0901-y

Geiger, R.D., Shieh, W.J., and Saluke, R.M. (1989). Carbon partitioning among leaves, fruits, and seeds during development of Phaseolus vulgaris L. Plant Physiology 91(1): 291-297. Doi: 10.1104/pp.91.1.291

Inzunza-Ibarra, M.A., Villa-Castorena, M.M., Catalán-Valencia, E.A., López-López, R., Sifuentes-Ibarra, E. (2018). Rendimiento de grano de maíz en déficit hídrico en el suelo en dos etapas de crecimiento. Revista Fitotecnia Mexicana 41(3): 283-290. 
Khan, M.B., Yousaf, F., Hussain, M., Haq, W.M., Lee, D.J., and Farooq, M. (2012). Influence of planting methods on root development, crop productivity and water use efficiency in maize hybrids. Chilean Journal of Agricultural Research 72: 556-563. http://dx.doi.org/10.4067/S07 18-58392012000400015

Kebede, A.Z., Melchinger, A.E., Cairns, J.E., Araus, J.L., Makumbi, D., Atlin, G.N. (2013). Relationship of line per se and testcross performance for grain yield of tropical maize in drought and well-watered trials. Crop Science 53: 1228-1236.

Krishnamurthy, L., Vadez, V., Devi, M.J., Serraj, R., Nigam, S.N., Sheshshayee, M.S., Chandra, S., and Aruna, R. (2007). Variation in transpiration efficiency and its related traits in a groundnut (Arachis hypogaea L.) mapping population. Field Crops Research 103(3): 189-197. https://doi.org/10.1016/j. fcr.2007.06.009

Lamers, J., van der Meer, T., Testerink, G. (2020). How Plants Sense and Respond to Stressful Environments. Plant Physiology 182: 1624-1635.

Mi, N., Cai, F., Zhang, Y., Ji, R., Zhang, S., and Wang, Y. 2018. Differential responses of maize yield to drought at vegetative and reproductive stages. Plant Soil Environment 64(6): 260-267. https://doi. org/10.17221/141/2018-PSE

Nezhadahmadi, A., Prodhan, Z.H., and Faruq, G. (2013). Drought tolerance in wheat. The Scientific World Journal 2013(1): 1-12. Doi: 10.1155/2013/610721

Pandey, V., and Shukla, A. (2015). Acclimation and tolerance strategies of rice under drought stress. Rice Science 22(4): 147-161. https://doi.org/10.1016/j.rsci.2015.04.001

Polania, J., Poschenrieder, G., Rao, I., and Beebe, S. (2017). Root traits and their potential links to plant ideotypes to improve drought resistance in common bean. Theoretical and Experimental Plant Physiology 29: 143-154. doi: 10.1007/s40626-017-0090-1

Rebolloza-Hernández, H., Cervantes-Adame, Y.F., Broa-Rojas, E., Bahena-Delgado, G., y Olvera-Velona, A. (2020). Fenotipeo y selección de líneas S1 segregantes de maíz tolerantes a estrés hídrico. Biotecnia 22(3): 20-28.

SAS. (2009). The SAS System Program release 9.1 for Windows. SAS Institute, Inc., Cary, North Carolina, U.S.A. Software of statistical analysis.

Tracy, S.R., Nagel, K.A., Postma, J.A., Fassbender, H., Wasson, A., and Watt, M. (2020). Crop Improvement from Phenotyping Roots: Highlights Reveal Expanding Opportunities Saoirse. Trends in Plant Science 25: 105-118. https://doi.org/10.1016/j.tplants.2019.10.015

Villalobos-González, A., López-Castañeda, C., Miranda-Colín, S., Aguilar-Rincón, V.H., y López-Hernández, M.B. (2016). Relaciones hídricas en maíces de Valles Altos de la Mesa Central de México en condiciones de sequía y fertilización nitrogenada. Revista Mexicana de Ciencias Agrícolas 7(7): 1651-1665.

Villalobos-González, A., López-Castañeda, C., Miranda-Colín, S., Aguilar-Rincón, V.H., y López-Hernández, M.B. (2018). Efecto del estrés hídrico y nitrógeno en las raíces de variedades hibridas y criollas de maíz (Zea mays L.). Agroproductividad 11(1): 3-8.

Villalobos-González, A., López-Hernández, M.B., Valdivia-González, N.A., Arcocha-Gómez, E., y MedinaMéndez, J. (2019). Variabilidad morfológica de maíz nativo (Zea mays L.) en la Península de Yucatán, México. Agroproductividad 12(11): 15-20.

Zhu, J., Brown, K.M., and Lynch, J.P. (2010). Root cortical aerenchyma improves the drought tolerance of maize (Zea mays L.). Plant, Cell and Environment 33: 740-749. doi: 10.1111/j.1365-3040.2009.02099.x 